\title{
Offentlig äldreomsorg som del i ett socialt medborgarskap ${ }^{1}$
}

\author{
STAFFAN BLOMBERG \& JAN PETERSSON
}

\begin{abstract}
Den svenska äldreomsorgen genomgick under förra seklet en omvandling frän att ha haft sin hemvist i fattigvården till att bli en institutionell rättighet för äldre medborgare. Under 1990-talet har emellertid förändringar $i$ omsorgens organisering och administration $i$ de svenska kommunerna bidragit till att det sociala medborgarskapets innebörd definierats om.
\end{abstract}

\section{Inledning}

I sin uppmärksammade uppsats "Citizenship and Social Class" (1950) betraktar TH Marshall det sociala medborgarskapet som "... a status bestowed on those who are full members of a community" (s18). Vid sidan av politiska och ekonomiska rättigheter konstitueras medborgarskapet av de sociala rättigheternas framväxt under 1900-talet. För Marshall var utvecklandet av universella sociala rättigheter det främsta medlet

Staffan Blomberg är doktorand i socialt arbete och universitetsadjunkt vid Socialhögskolan i Lund och forskar kring förändringar i äldreomsorgens organisering. Jan Petersson är docent och universitetslektor vid samma institution och forskar kring välfärdsprioriteringar i kommuner. i skapandet av det sociala medborgarskapet. Att socialpolitiken är universell innebär att den är riktad till alla medborgare med ett legitimt behov samt kollektivt finansierad. Kritiker (exempelvis Tilly 1998), såväl som Marshall själv, har pekat på att lika och universella rättigheter till alla inte förmår att överbrygga de strukturellt grundade ojämlikheter som är den primära orsaken till den sociala stratifieringen i samhället. I den svenska politiska diskursen har emellertid tilltron till att omfattande sociala rättigheter kan vara en jämlikhetsskapande och integrativ kraft i samhället haft en stark förankring. Tankegången

1 Arbetet med denna artikel har möjliggjorts med stöd från FAS. 
har även haft ett starkt stöd från vetenskapligt håll. Exempelvis har statsvetare ( $t$ ex Rothstein 1994) och sociologer ( $t$ ex Giddens 1998), i Richard Titmuss anda, argumenterat kraftfullt för att endast en universell socialpolitik kan skapa en moraliskt grundad känsla av samhörighet mellan människor, vilket kan betraktas som en förutsättning för ett socialt medborgarskap. I forskning och debatt kontrasteras ofta den universella socialpolitikens fördelar mot den selektivas nackdelar. Huvudargumentet är att en selektivt utformad socialpolitik motverkar en integrering av de grupper som politiken riktar sig till genom att den pekar ut och i värsta fall stigmatiserar mottagarna (se t ex Titmuss, 1968; 1974).

Kopplingen mellan sociala rättigheter och det sociala medborgarskapet återkommer i modern välfärdsforskning.Vid jämförelser mellan länder eller $\mathrm{i}$ ett land över tid tar forskningen ofta sin utgångspunkt i de formella regler, exempelvis ersättningsbelopps storlek och kvalifikationsvillkor, som gäller för olika välfärdsprogram. Denna typ av komparativa analyser återfinns bland annat i Gösta Esping-Andersens välkända bok "Three Worlds of Welfare Capitalism" (1990). En granskning utifrån de formella reglerna ger en fingervisning om sociala rättigheters innehåll och omfattning $\mathrm{i}$ olika länder och vid skilda tidpunkter och som en första approximation är de $i$ denna egenskap användbara. Ett problem med att avgränsa analysen på detta sätt är emellertid att det är svårt att veta vad en rättighet egentligen omfattar utan att också studera regelverkens tillämpning i praktiken. En studie av socialbidraget i OECD-länderna visar exempelvis att själva handläggningsprocessen och de konkreta sorteringsmekanismerna ofta skiljer sig åt mellan länder (Eardley et al 1996) $)^{2}$. Detta problem accentueras med omfattningen på det tolknings- och handlingsutrymme som lagen medger. Den svenska äldreomsorgen styrs av en ramlagstiftning (Socialtjänstlagen) som öppnar upp ett stort handlingsutymme för hur lagen kan tillämpas. I Sverige har kommunerna det finansiella och administrativa ansvaret för äldreomsorgen och har alltid haft en stor frihet vad beträffar valet av $t$ ex omsorgsformer. Decentraliseringen och ramlagskonstruktionen bidrar till att den lokala praxisen kring vad rätten till bistånd de facto innehåller kan variera både mellan kommuner och över tid. I varierande grad kan även professionella yrkesgrupper och byråkrater agera självständigt i tillämpningen av de regelverk som finns (Prottas 1979; Lipsky 1980). Utrymmet för denna självständighet (discretion) ökar enligt Hill (1997) med graden av ärendekomplexitet och graden av delegation.

I denna artikel tar vi vår utgångspunkt i hur det sociala medborgarskapet konstrueras i relation till rättigheters faktiska innehåll snarare än hur de kodifieras i lagen. Det innebär en metodmässig omformulering av problematiken kring medborgarskap och rättigheter från

2 Resonemanget gäller naturligtvis även vid jämförelser lokalt inom länder $\mathrm{t}$ ex vid kommunjämförelser. 
att angripa problemet "uppifrån och ner" till att gå "nerifrån och upp». Vår utgångspunkt för analysen är alltså att medborgarskapet inte kan frikopplas från det sätt som rättigheterna organiseras och administreras. På denna (organisations-) nivå översätts och omsätts lagregler och riktlinjer till handlingar. Detta har poängterats av Bryan S Turner när han definierar det sociala medborgarskapet som ...nthe set of practices (juridical, political, economic and cultural) which define a person as a component member of society, and which as a consequence shape the flow of resources to persons or social groups" (Turner 1993:2 - vår kursivering). På samhällsnivå reflekterar medborgarskapet vidare (institutionaliserade) förväntningar kopplade till rättigheternas materialisering.

Artikelns syfte är att relatera äldreomsorgens organisatoriska omvandling till begreppen socialt medborgarskap och sociala rättigheter. Inledningsvis tecknas en bild av det sociala ansvarets organisering och institutionalisering i ett historiskt perspektiv. Det blir tydligt att den svenska utvecklingen karaktäriseras av att ett omfattande offentligt ansvar för de äldres vård och omsorg, boende och ekonomiska trygghet institutionaliseras. Under 1990-talet förändras åter bilden och vår slutsats av att betrakta denna utveckling i ett historiskt perspektiv är att parallellt med att de sociala rättigheterna preciseras vad gäller t ex person, situation och hjälpinsatser så försvagas det sociala medborgarskapet.

Mot bakgrund av dessa inledande fun- deringar kommer vi att använda oss av följande principskiss för att närmare utreda sambandet mellan det sociala medborgarskapet och de sociala rättigheterna inom äldreomsorgen:

Socialt medborgarskap

Sociala rättigheter

- som formella utfästelser

>Materialisering

Sociala rättigheter

- som faktiskt utfall

Låt oss sammanfatta vår utgångspunkt. $\mathrm{Vi}$ har argumenterat för att socialt medborgarskap i grunden är ett immateriellt begrepp. En första fingervisning om dess materiella innehåll ges av de formella utfästelserna i den nationella lagregleringen ${ }^{3}$. Inom äldreomsorgen översätts de formella utfästelserna i en lokal kontext och de sociala rättigheternas faktiska utfall bestäms vid en biståndsbedömning som ger utrymme för variation. Att gå ner till denna nivå där rättigheter de facto materialiseras är helt avgörande för en förståelse av den svenska äldreomsorgen som en del i ett socialt medborgarskap. Utgångspunkten rimmar väl med Antoinette Hetzlers (1994) analys av handikappersättningen där hon pekar på betydelsen av att stu-

3 I sällsynta fall kan man påstå att materialiseringen faktiskt tar form på denna nivå. Exempelvis den svenska ATP-pensionen utgör ett sådant exempel till följd av att det är nationellt och detaljreglerat vilket skänker handläggningen en rent mekanisk prägel utan utrymme för "discretion". 
dera handläggningsrutiner och praxis på försäkringskassorna där politiken genomförs och mottagarnas krav möts. Därmed görs också en åtskillnad mellan medborgarskapets formella sida och dess innehållsmässiga (Brubaker, 1989; 1992). I princip instämmer vi även i vad Kerstin Gynnerstedt (2001) framfört i en tidigare artikel i denna tidskrift, nämligen att det sociala medborgarskapet kan betraktas ur ett lagligt, ett organisatoriskt och ett implementeringsperspektiv. Vi vill emellertid betona vikten av en sammanhållen analys av de tre perspektiven.

\section{Enförståelseram}

Ivar Lödemel argumenterar i sin bok The Welfare Paradox (1997) för att Richard Titmuss distinktion mellan en residual och en institutionell modell för välfärd fortfarande utgör det bästa analytiska redskapet för att fånga skillnaden mellan den traditionella fattigvårdens och den moderna socialpolitikens karaktär och inriktning ${ }^{4}$. I sin bok konstruerar denne

4 Distinktionen mellan en institutionell och residual modell utvecklades av Wilensky och Lebeaux i mitten av 1960-talet i syfte att skilja mellan olika synsätt på socialt arbete. Jfr Lorentz (1998). Tillämpningen av modellerna i socialpolitiska analyser förknippas emellertid med Titmuss. Titmuss själv drog bara upp konturerna för typologierna $i$ en sammanställning av föreläsningsanteckningar utgivna efter hans död (Titmuss 1974) men de har tillämpats och vidareutvecklats av andra (ex Mishra 1981, Esping-Andersen 1990). ett index med indikatorer för institutionella och residuala inslag vad gäller socialbidraget och socialförsäkringen. Med utgångspunkt från denna idé skulle ett index ${ }^{5}$ för äldreomsorgen kunna se ut som figur 1 .

Den fattigvårdspräglade (residuala) omsorgsmodell som präglade den svenska äldreomsorgen vid 1900-talets ingång var en (socken-) kommunal angelägenhet. Äldreomsorgen riktades till individer med stora behov och för vilka inga närstående sörjde. I kommunerna ställdes höga krav på anhöriga att själva ta hand om sina gamla och ett omhändertagande inom fattigvården kunde enbart komma ifråga i de fall detta inte var möjligt. Systemet var i hög grad subsidiärt till sin form och garanterade i princip enbart överlevnad (minimistandard). Prövningen av legitima behov för kommunala insatser var minimalistisk. Med en minimalistisk handläggningsrutin avser vi en bokstavlig tolkning av lagen i relation till den enskildes behov och en aktiv prövning av i vilken utsträckning det

5 När vi här ställer en residual modell mot en institutionell har vi hämtat motsatsparen ur en historisk omvandling som markeras av en övergång från en fattigvårdspräglad äldreomsorg till en medborgarorienterad "modern" form. Vi vill peka på att vi i vår analys av moderna trender längre fram kommer att hävda att vi idag kan iaktta att residuala inslag återigen börjar prägla äldreomsorgen. Då använder vi emellertid de båda motsatsparen institutionell och residual som teoretiska/principiella motsatser. Det finns exempelvis ingen anledning att tro att ett ökande lekmannainflytande skulle kunna vara ett inslag i en modern omvandling mot ökad selektivitet och residualisering. 
Figur 1.

\begin{tabular}{|c|c|c|}
\hline Indikator & Institutionell & Residual \\
\hline O ffentligt ansvar & Ö vergripande & Subsidiärt \\
\hline Ansvarig myndighet & Staten & Kommunen \\
\hline Rättslig grund & Ramlagstifning & Speciallagstiftning \\
\hline Handläggningsrutin & Responsiv & Minimalistisk \\
\hline Beslutsfattare & Tjänstemän (Professionella) & Lekmän \\
\hline Målgrupp & $\begin{array}{c}\text { Alla medborgare } \\
\text { (universalitet) }\end{array}$ & $\begin{array}{c}\text { Fattiga } \\
\text { (selektivitet) }\end{array}$ \\
\hline Legitima behov & Stora och små & Stora \\
\hline Ambitionsnivå & N ormalstandard & Ö verlevnad \\
\hline
\end{tabular}

verkligen föreligger ett hjälpbehov och vilka alternativ till offentlig hjälp som finns (jfr Hetzler 1994 a a.)

En institutionell modell för välfärd markerar vanligen att socialpolitiken blivit en nationell angelägenhet och att staten fått en markerad roll. Ambitionsnivån ökar både genom att politiken riktar sig till alla medborgare och att stöd aktualiseras både vid stora och små behov. Prövningen av behov speglar ett ideal om responsivitet $i$ ärendehandläggningen. Med responsivitet avses att de individuella omständigheterna utgör utgångspunkten för behovsprövningen. Den moderna ramlagstiftningen kan ses som ett utryck för att skapa det handlingsutrymme för tjänstemannen som en responsiv prövning i princip kräver.

Den institutionella modellen för välfärd ses vanligtvis som ett naturligt inslag i en modern välfärdsstat vilken lämnat fattigvårdstraditionerna och den residuala modellen för välfärd bakom sig. Synen på att den moderna institutionella välfärds- staten representerar en lineär och logisk utveckling och/eller kan förklaras som en reaktion på fattigvårdens residuala system har emellertid kritiserats. En form av kritik tar sin utgångspunkt $i$ att traditionell fattigvård och modern socialpolitik är väsenskilda till form och innehåll och dessutom representerar olika syften. De är frikopplade från varandra och varje försök att finna linjer (kausala mekanismer) i utvecklingen över tid eller vid jämförelser av exempelvis olika länder kommer att misslyckas. Lödemel (1997) argumenterar emellertid för att man inte kan betrakta den moderna (institutionella) socialpolitiken vare sig som väsensskild från den traditionella (residuala) fattigvården eller som en funktionell (logisk) konsekvens av samhällsutvecklingen. Kopplingar mellan den traditionella fattigvården och den moderna socialpolitiken föreligger både i form av en kontrasterande politik och $i$ att värderingar med rötter i fattigvården fortfarande upprätthålls. I praktiken skall distinktionen mellan institutionell och residual välfärd 
inte ses som en dikotomi utan betraktas som ett kontinuum (en institutionell socialpolitik kan omfatta residuala inslag och omvänt). Det blir därför mer intressant att tala om riktningar i ett utvecklingsförlopp snarare än tillstånd inom äldreomsorgen.

I den närmast följande genomgången av äldreomsorgens utveckling i Sverige används förståelseramen för att strukturera empirin.

\section{Mot ett ökat of fentligt ansvar}

Genom gradvis växande åtaganden för vård, omsorg och försörjning har välfärdsstaten, vid sidan av familjen, under 1900-talet kommit att få en alltmer dominerande roll som garant för medborgarnas trygghet. När det gäller organiseringen av det sociala ansvaret menar Roger Qvarsell (1993; 1995) att utvecklingen kännetecknas av en ständig kamp kring ansvarsfördelningen samt av en differentiering vad gäller hjälpinsatsernas utformning och inriktning. Var gränserna går för statens, familjens och marknadens ansvar när det gäller de äldre har omförhandlats under 1990talet vilket visar att Qvarsell inte enbart beskriver en historisk företeelse.

Fram till 1950-talet organiserades det offentliga ansvaret för äldrevården i Sverige inom ramen för den kommunala fattigvården. Inom fattigvården hade kommunerna (tidigare socknarna) tillsammans med kyrkan och senare, från slutet av 1700-talet och långt in på 1900-talet, även frivilligorganisationer det administrativa och finansiella ansvaret för äldrevården. Lagstiftningen lämnade ett stort handlingsutrymme åt kommunerna när det gällde att organisera och tillhandahålla hjälp för de äldre. I den mån staten agerade handlade det företrädesvis om att genom lagstiftningen fastslå ramar för verksamheten (Edebalk 1991). Vem som var berättigad till hjälp avgjordes av fattigvårdsstyrelserna (senare socialnämnder). Det var således lekmän i form av lokala politiker och andra betrodda samhällsmedborgare som beslutade om tilldelningen. Vad gäller hjälpinsatsernas form och innehåll kom jordbrukssamhällets former för öppenvård successivt att ersättas med sluten vård på institutioner med olika form och inriktning. Att vara omhändertagen inom fattigvården medförde inte bara ett rumsligt avskiljande utan innebar även ett utanförskap i social mening. Fattigvård var ingen rätttighet och ett offentligt hjälpbehov var inte förenligt med en formell status som fullvärdig samhällsmedborgare. Kommunerna kunde länge hävda sin husbonderätt gentemot understödstagarna och på fattigstugor, försörjningsinrättningar och ålderdomshem avspeglades den underordnade positionen i de regler och riktlinjer som den intagne hade att följa (Edebalk 1990).

Ett ökat offentligt ansvarstagande och en förändrad gränsdragning (ansvarsfördelning) mellan staten och den enskilde (familjen) avspeglas i den differentiering av hjälpinsatsernas utformning och inriktning som inleddes på 1950-talet. Under 1950- och 1960-talet utvecklades nya kollektiva vård- och omsorgsformer inom äldreomsorgen som innebar att de förut 
så tydliga gränserna mellan institutionslivet och det självständiga livet luckrades upp (Åman 1976). Genom att kroniskt och svårt sjuka skulle vårdas på särskilda institutioner kom insatserna inom äldreomsorgen att fokusera på de äldres behov av omsorg och social service. Utbyggnaden av hemtjänsten utgjorde ett definitivt brott med institutionstanken genom att fler gamla kunde få den hjälp de behövde i sitt eget hem. Införlivandet av hemtjänsten i den offentliga sektorn från 1950-talet och framåt avspeglar en utveckling där föreställningen om ett omfattande offentligt omsorgsansvar institutionaliserades. Att äldreomsorgen vände sig till alla med behov av service, inte enbart sjuka eller fattiga människor, innebar i praktiken att äldreomsorgen lyftes ut från det myndighetsbaserade sociala arbetet (med sina rötter i fattigvården) och istället blev ett självständigt offentligt serviceområde (Sunesson 1990). Utvecklingen på 1970talet pekar mot att äldreomsorgen alltmer erhöll universella drag genom att den blev en integrerad institution i samhället vilken tillhandahöll sociala tjänster för alla medborgare med behov, små som stora, av hjälp. Äldreomsorgen utvecklades i riktning mot att vara en möjlighet, självklarhet och verklighet för samtliga landets åldringar. Att omsorg blev något alla hade rätt till och med tiden ansåg sig ha rätt till (institutionaliserade förväntningar) manifesterade den normalisering som ägt rum ${ }^{6}$.

6 I sitt anförande vid Forsa-symposiet 1990 diskuterade Sune Sunesson förändringen under rubriken Att spränga fattigvårdsskalet (Sunesson 1990).
Sammanfattningsvis kan man säga att äldreomsorgens residuala karaktär och inriktning var påtaglig långt in på 1950-talet. Först med utbyggnaden av nya vård- och omsorgsformer och hemtjänstens expansion under 19601970-talet blev äldreomsorgen en social service med tydliga institutionella drag. Av rötterna i fattigvården fanns emellertid vissa spår kvar. Det tydligaste var kanske de kommunala variationer som framträdde i bristen på en stark nationell styrning.

\section{Förändringar i äldreomsorgen under 1990-talet}

\section{Reformer och nya organisationsideal}

Under 1990-talet sätter ett antal processer in som pekar i skilda riktningar. Reformeringen av de kommunala förvaltningsorganisationerna anknyter på ett övergripande plan till decentraliseringen av (välfärds-) staten och de förändrade organisationsideal som under 1990-talet utgjort ett nytt inslag och en drivkraft i denna utveckling. Decentraliseringen har inneburit både ett utvidgat lokalt verksamhetsansvar (kommunalisering) och ett ökat handlingsutrymme (autonomisering) för kommunerna att organisera och implementera de offentliga åtagandena (Lindquist 1998). För äldreoch handikappomsorgens vidkommande har ett antal statliga reformer under 1990-talet på olika sätt bidragit till att kommunernas verksamhets- och omsorgsansvar utvidgats (Blomberg, Edebalk 
och Petersson, 1999) ${ }^{7}$. I en betraktelse av (välfärds-) statens organisering menar Rune Premfors (1998) att utvecklingen karaktäriseras av en trend mot ökad autonomi bland de organisationer som tillsammans utgör den offentliga sektorn (staten). Traditionellt har den kommunala självstyrelsen inneburit att organisationer inom staten i vissa avseenden framstår som självständiga (och ibland olikartade). Under 1990-talet har emellertid offentliga förvaltningar (och andra verksamheter inom den offentliga sektorn) tvingats till eller själva valt att i ökad utsträckning betrakta sig som (fristående) organisationer (Premfors 1998). Uppluckringen av monopolet för produktion av välfärdstjänster och möjligheten till friare organisationsformer inom de offentliga förvaltningarna är exempel på reformer som har skapat förutsättningar för (och bidragit till) att nya former för organisering, kontroll och styrning utvecklats inom de kommunala förvaltningarna. I många kommuner har

7 Ädelreformen 1992 syftade bland annat till att skapa bättre förutsättningar för ett effektivt resursutnyttjande inom äldre- och handikappomsorgen. Landstingens sjukhem kommunaliserades och de kommuner som ville kunde efter överenskommelse även få överta hemsjukvården Reformen följdes under 1994-95 av en handikappreform som bl a omfattade lagen om stöd och service till vissa funktionshindrade (LSS) och lagen om assistansersättning (LASS) samt en psykiatrireform (PsykÄdel). Med undantag av akuta sjukvårdsinsatser (landstingen) har kommunerna idag hela ansvaret för att de äldres fysiska och psykiska behov tillgodoses. mer marknadslika organisationsformer eftersträvats. För äldreomsorgens del har förändringarna konkret inneburit att verksamheten i många kommuner konkurrensutsatts genom att delar av verksamheten privatiserats eller lagts ut på entreprenad (Socialstyrelsen 1996 och 1999) ${ }^{8}$. Trydegård (2001) förlägger genombrottet till åren 1991-95 och därefter har denna mix blivit etablerad.

\section{Nya prioriteringar}

Utvecklingen inom äldreomsorgen ger en tydlig bild av att resurser har prioriterats om. Fram till mitten av 1970-talet ökade täckningsgraden (antalet äldre med hjälp i relation till det totala antalet äldre i befolkningen) snabbt men därefter har andelen äldre med hemtjänst minskat kraftigt. Andelen hjälpta som 1975 utgjorde 25\% av de äldre hade 1996 minskat till 10\%. För jämförelsens skull kan nämnas att detta motsvarar äldreomsorgens täckningsgrad i början av 1960-talet. Att även hemtjänstmottagarnas sammansättning förändrats avspeglar sig i att den genomsnittliga hjälptiden för den som har hemtjänst har ökat väsentligt de senaste 15 - 20 åren.

8 En entreprenad innebär att driftsansvaret för $t$ ex ett vårdboende eller ett hemtjänstdistrikt överlåts till ett privat (icke-offentligt) företag. En privatisering äger rum när kommunen säljer ut en verksamhet eller helt enkelt upphör med tjänsteproduktionen. I praktiken innebär en privatisering att kommunerna köper de vård- och omsorgstjänster de inte längre själva vill (eller kan) producera. För kommunala erfarenheter och effekter inom äldreomsorgen under senare år se Svensson \& Edebalk (2001) 
Idag riktas alltmer av resurserna inom äldreomsorgen mot ett relativt sett mindre antal äldre med stora hjälpbehov (Daatland 1997, Sundström 1997 och Szebehely 2000). Omvänt innebär förskjutningen mot allt äldre och omvårdnadsbehövande hemtjänsttagare att andelen äldre med mer vardagliga behov av hjälp (det kommunerna kallar service) minskar inom äldreomsorgen. I många kommuner kan utvecklingen beskrivas som en förskjutning från en traditionell socialt inriktad hemtjänst mot en modern medicinskt orienterad omsorg med starka inslag av rehabilitering. I praktiken har en överflyttning ägt rum som inneburit att såväl psykiskt som fysiskt sjuka äldre lämnat sjukvården och i stor utsträckning återfinns i den kommunala äldreomsorgens traditionella omsorgsformer som ålderdomshem och serviceboenden ${ }^{9}$. Inom äldreomsorgen har prioriteringarna av äldre med stora vård- och omsorgsbehov medfört att servicebrukarna fått lämna äldreomsorgen (Szebehely, 1998 a, b, c samt Blomberg, Edebalk och Petersson 1999).

\section{Ökad selektivisering}

Att hemtjänsten idag inte vänder sig till alla utan enbart de med omfattande vårdoch omsorgsbehov är ett tecken på en selektivisering. Alla som har ett visst behov har visserligen rätt att få detta tillgodosett men när antalet med legitima behov är litet

9 Under senare tid har man i många kommuner börjat använda sig av begreppet vårdboende som en gemensam beteckning för traditionella omsorgsformer $\mathrm{t}$ ex ålderdomshem och sjukhem och mer moderna vårdformer som gruppboende för dementa. är det inte självklart att detta utgör ett kriterium på universalism. Målgruppen är inte de fattiga (negativ selektivitet) utan de med stora behov (positiv selektivitet). De förändrade användarmönstren inom äldreomsorgen uttrycker en förändrad relation mellan de äldre och deras sociala nätverk, välfärdsstaten och marknaden. De visar också att sociala rättigheter inte innebär att konflikter om resursernas fördelning och vilka prioriteringar mellan olika individer och grupper som ska göras upphör när de institutionaliserats. När det gäller utformningen och inriktningen av insatserna kan man möjligen tala om att en de-differentiering ägt rum - olika insatser för äldre med olika behov har ersatts av likartade insatser för äldre med samma (vård-) behov. Vad gäller välfärdsstatens åtaganden i stort har Rune Premfors (1998) hävdat att någon avdifferentiering inte skett trots de nedskärningar som ägt rum de senaste decennierna. För äldreomsorgens vidkommande vill vi alltså hävda det motsatta.

I en studie för Socialstyrelsen 1998 (Blomberg, Edebalk \& Petersson a a) pekade vi på att den restriktivare behovsbedömningen sammanföll med en byråkratisering av handläggningen. Förändringen föregicks inte av förändrade kommunala riktlinjer (åtminstone inte skriftliga) eller ny lagstiftning. En slutsats var att nya kriterier för kategoriseringen av klienter/brukare utvecklats i förvaltningarna som ett svar på sparkrav (budgetstyrning snarare än riktlinjer) samt för att underlätta samverkan mellan olika delar inom den kommunala äldreomsorgen eller mellan 
organisationer (privata eller kommunala vårdbolag) i de fall bedömningarna av hemtjänstmottagarnas behov inte sammanföll med tillhandahållandet av hjälpinsatserna.

Parallellt med byråkratiseringen av handläggningsrutinerna indikerade vår studie att efterfrågan på expertkunskap hade ökat. Det gällde såväl administrativ kompetens som specialiserad kunskap om (de nya) gruppernas problem och behov. Denna tendens till professionalisering (i vid mening) av biståndsbedömarna tog sig uttryck $i$ att dessa genom intern och extern utbildning tillgodogjorde sig en gemensam kunskapsbas för sina bedömningar, dessutom förväntades nya biståndsbedömare i hög utsträckning ha en akademiska examen. Det framgick vidare $\mathrm{i}$ vår studie att specialiseringen och standardiseringen (vilka arbetsuppgifter och vad som krävs för att utföra dessa) har ökat parallellt med att kraven på professionell kompetens har skärpts. Med viss reservation förefaller det emellertid inte som att biståndshandläggarnas yrkesutövning kommit att vila på en professionell auktoritet ${ }^{10}$. Vilka uppgifterna är och hur dessa skall lösas verkar snarare vara en fråga om val av organisationsform. I den traditionella organiseringen av äldreomsorgen förenades myndighetsutövningen med ett driftsansvar (jfr ovan). Dessa arbetsuppgifter är idag vanligtvis

10 I en professionell byråkrati grundas yrkesutövningen snarare på den auktoritet den professionella expertisen ger snarare än på organisationsspecifika (byråkratiska) regler (Ahrne 1999). skilda åt. Specialiseringen kan ses som ett utryck för att biståndsbedömaren ska kunna fullgöra den huvuduppgift de vanligen tillskrivs och tillskriver sig själva nämligen att förbättra rättssäkerheten (pågående forskning). I vissa kommuner går man ett steg längre och formaliserar inte bara behovsbedömningen utan standardiserar också hjälpinsatserna. Detta innebär att den äldres behov anpassas efter de insatser som erbjuds, snarare än att de individuella hjälpbehoven i sig ligger till grund för insatsernas sammansättning och innehåll. I den offentliga verksamhetens dialektik, för att anknyta till Lipsky (1980), har idén om flexibilitet som tidigare präglade medborgarens möte med kommunernas äldreomsorg, under 1990-talet ersatts av en idé om lika behandling.

\section{Sociala rättigheter och medborgarskap}

Låt oss nu avslutningsvis göra ett försök att operationalisera det sociala medborgarskapet för att kunna relatera begreppet till äldreomsorgens historiska utveckling. Mot bakgrund av resonemangen i inledningen har vi valt att beskriva det som ett begrepp i tre nivåer till vilka vi sökt precisera operationella nyckelord och empiriska indikatorer. Nivåerna betraktar tre dimensioner av de sociala rättigheternas betydelse för konstruktionen av (och innehållet i) ett socialt medborgarskap - Att ha en rätttighet (formella regler) Att få sin rättighet (materialisering) och Att viljalanse sig ha rättigheten (värderingar). 
De formella reglerna (lagar och riktlinjer) anger det offentliga ansvarets gränser. Vi tänker oss här att politikens universella styrka står i direkt proportion till det offentliga ansvarets omfattning. En selektiv politik innebär att ansvaret för den enskilde att själv tillgodose sina omsorgsbehov ökar. Utvidgningen av det offentliga omsorgsansvaret under efter 1950 innebar att äldreomsorgen fick karaktär av medborgerlig rättighet genom ett ökat offentligt åtagande. Under 1990-talet ser vi emellertid en omvänd utveckling. Ett minskat offentligt ansvar innebär att kraven ökar på den äldres sociala nätverk (främst familjen). Szebehely (2000) visar på att resurstilldelningen till äldreomsorgen i fasta priser visserligen ökat under perioden 1993-97 men att det i relation till ökningen av antalet äldre innebär minskade resurser. Med hänvisning till Batljan och Lagergren (2000) pekar hon på att det inte kan motiveras av att de äldres hälsa och funktionsförmåga förbättrats i motsvarande grad. Slutsatsen måste bli att det offentliga ansvarets gränser är under omprövning i riktning mot mindre åtaganden. I en selektiviseringsprocess ökar även utrymmet för marknadslösningar och frivilliga insatser. I vår och annan forskning (Trydegård 2000) framgår tydligt att en välfärdspluralistisk hållning är på väg att växa fram. Kommunerna arbetar aktivt för att dra in frivilliga krafter i omsorgen. På många håll uppmanas kyrkan och de äldre själva att organisera omsorgsinsatser $t$ ex besöksverksamhet, lässtunder och ledsagarhjälp. Till följd av ett minskat serviceutbud inom det offentligas ram hänvisas de äldre i många kommuner till marknaden för att lösa sina behov av service. Det är inte ovanligt att biståndshandläggarna numera förmedlar kontakten med lokala städfirmor och handlare som är villiga att hjälpa till med inköp och hemkörning av matvaror. Vidare förväntas anhöriga i stor utsträckning utföra omsorgsinsatser som ersättning för eller som komplement till kommunens äldreomsorg. Detta utgör exempel på hur omtolkningar av rätten till bistånd eller uttryckt på ett annat sätt hur behoven »kan tillgodoses på annat sätt»kan minska det kommunala omsorgsansvaret. I kommunernas tillämpning av socialtjänstlagens biståndsparagraf ersätts det offentliga omsorgsansvaret i ökad utsträckning av en subsidiaritetsprincip som vägledande norm, vilket också återspeglas i förändringen av biståndparagrafen 1998.

I relation till materialiseringen använder vi oss av tolkningsföreträde som nyckelord. Med detta avser vi i vilken utsträckning

\begin{tabular}{|c|c|c|}
\hline Nivå & Nyckelord & Incikator \\
\hline $\begin{array}{c}\text { Formella regler } \\
\text { (Att haen rättighet) }\end{array}$ & D et offentliga ansvarets gränser & O mso rgens utförare \\
\hline $\begin{array}{c}\text { Materialisering } \\
\text { (Att fåsin rättighet) }\end{array}$ & Tolkningsföreträde & $\begin{array}{c}\text { Professionsmakt } \\
\text { Byråkratisering }\end{array}$ \\
\hline $\begin{array}{c}\text { Värderingar } \\
\text { (Att vilja/ansesigha } \\
\text { rättigheten) }\end{array}$ & Legitimitet & $\begin{array}{c}\text { Klyfta mellan förväntningar och } \\
\text { faktiskt utfall }\end{array}$ \\
\hline
\end{tabular}

Blomberg \& Petersson: Offentlig äldreomsorg som del i ett socialt medborgarskap 
brukaren själv ges möjlighet att påverka formuleringen av sitt behov och utformningen av insatser. Uppkomsten av ett omsorgsyrke innebär en ökande professionalisering och professionsmakt. De yrkesverksamma tillskriver sig och tillskrivs i denna process en ökad auktoritet vad gäller att veta bäst vilka de behov är som ska tillgodoses och vilka insatser som är bäst lämpade. Parallellt med en professionalisering (i vid mening) har administrationen inom den kommunala äldreomsorgen byråkratiserats och i vissa fall har även de hjälpinsatser kommunen erbjuder standardiserats ( $\mathrm{t}$ ex med avseende på omfattning, inriktning och arbetssätt). I flera av de kommuner vi undersöker finns tecken på att bedömningarna i allt större utsträckning regleras av organisationsbestämda klientgrupper och förutbestämda serviceinsatser (jfr Hasenfeld 1983). En byråkratisering av handläggningen innebär i detta fall en formalisering. Byråkratiseringen som syftar till formell lika behandling (och ransonering av resurser) leder (i bästa fall) till att rättsäkerheten för den enskilde ökar samtidigt minskar emellertid de äldres möjligheter att få gehör för sin individuella situation. En indikation på att det verkligen har skett en förändring på detta område är att biståndsbedömare med lång erfarenhet $\mathrm{i}$ våra intervjuer (pågående forskning) uttrycker ett problem med att man inte kan vara lika flexibel som tidigare i relation till de äldre. Biståndsbedömare med kort erfarenhet (men välutbildade) inom äldreomsorgen är i hög grad upptagna av att göra formellt rätt.

Antoinette Hetzler (1994) har i sina studier av hur försäkringskassan tillämpar rätten till handikappersättning visat att handläggningsrutinerna på vissa kassor karaktäriseras av att individer betraktas och bemöts som subjekt (dialogmönster), medan praxis på andra ställen följer ett minimalistiskt mönster vilket innebär att individerna behandlas som objekt (i relation till myndighetsutövningen). Hetzler knyter de olika tillämpningsmönstren till det sociala medborgarskapet genom att dessa bidrar till att forma det hon kallar "den offentliga identiteten". Den offentliga identiteten (eller medborgarskapets innehåll) skapas i länken mellan den subjektiva upplevelsen av en rättighets status och rättighetens faktiska (objektiva) innehåll. Det senare bestäms bl a av hur olika myndigheter (som $t$ ex försäkringskassan) tillämpar regelsystemen (se Hetzler a a , s 20ff).

I de kommuner vi undersöker finner vi också att professionella normer inkorporeras i äldreomsorgens målformuleringar och riktlinjer. En trend är att ett (traditionellt) omsorgsorienterat synsätt är på väg att ersättas av ett (modernt) rehabiliterande och omvårdnadsorienterat synsätt (Blomberg, Edebalk \& Petersson a a). Denna process har påskyndats genom Ädel-reformen i så motto att sjukvården gjort en tydligare entré i äldreomsorgen. Ett rehabiliterande arbets- och synsätt anknyter teoretiskt till det salutogena perspektivet, vilket tar utgångspunkten $i$ att alla insatser skall ta sikte på att hålla det friska vid liv. En praktisk konsekvens av detta synsätt är att man kan argumentera för att serviceinsatser inte motverkar utan snarare påskyndar omsorgsbehovets tillväxt. Den äldre ska göra så mycket han eller hon kan själv. Den 
professionellt motiverade minskningen av äldreomsorgsinsatser har inte svårt att få ett politiskt gehör.

När professionella normer tillåts styra en offentliga äldreomsorgens inriktning och omfattning och handläggningen av behovsbedömningen byråkratiseras minskar utrymmet för den enskilde att vara delaktig. Sett ur vårt perspektiv är det en indikation på att det sociala medborgarskapet försvagats.

Slutligen är de värderingar som kringgärdar äldreomsorgen betydelsefulla för dess legitimitet i samhället. Under den första perioden utgjordes målgruppen för äldreomsorgen av sjuka och fattiga. Den omvandling av äldreomsorgen som skedde under mellanperioden medförde en dramatisk förändring och nu kom alla äldre att både få rätt till och med tiden anse sig ha/vilja ha rätt till äldreomsorg. I statistiken över brukare kan man utläsa dess ökande popularitet. Denna nya syn var naturligtvis framför allt sprungen ur politikens nya materiella innehåll. Det är lätt att se den dialektik som präglar sambandet mellan värderingar och politikens utformning.

Under den senaste 10-15-årsperioden har äldreomsorgen återigen börjat vända sig mot gruppen sjuka medan de med mindre omsorgsbehov stängs ute. Klyftan mellan vad äldre idag anser sig ha rätt till och vad man faktiskt har (får) rätt till är kanske på väg att vidgas och därmed tilliten till äldreomsorgen. En indikation på en sådan klyfta är att ett stort antal individer som beviljats bistånd inte får detta verkställt. I princip kan man inte tala om universella rättigheter när det finns köer (Stjernö 1999). Vidare ansöker individer om hjälpinsatser som inte längre tillhandahålls. Andra tar vissa hjälpinslag för givna men blir utan till följd av att man inte formellt ansökt om dem (pågående forskning). Under den sista perioden har också äldreomsorgens kvalitet ifrågasatts i media. Detta skulle också kunna tas som intäkt för en ökande klyfta mellan de institutionaliserade förväntningarna och de materialiserade rättigheterna. Speciellt de privata utförarna har blivit utsatta för kritisk granskning och olika former av "missförhållanden" har uppmärksammats. Arbetstempot, arbetsformerna och arbetsmiljön inom äldreomsorgen har också problematiserats och frågan har ställts om de kvantitativa nedskärningarna går ut över det kvalitativa arbetet inom omsorgen. Huruvida dessa omständigheter påverkat synen på den offentliga äldreomsorgen är omöjligt att uttala sig om. En indikation på att så kan vara fallet är emellertid den ökade misstro som under 1990-talet människor riktat mot politiker och det politiska systemet (Möller 1998).

\section{Avslutning}

Marshalls analys av det sociala medborgarskapets materialisering stannar i stor utsträckning vid den legala/formella dimensionen. För denne består det sociala medborgarskapet av en formell status relaterad till lagfästa rättigheter. Vår utgångspunkt i denna artikel är, vilket redan torde ha framgått, att man även måste begrunda hur rättigheterna materialiseras och vilka förväntningarna kring dem som institutionaliseras för att bestämma det sociala medborgarskapet. Vi har lyft in begrep- 
pen tolkningsföreträde och legitimitet i analysen som centrala indikatorer för dess bestämning.

Gynnerstedt (2001) har bidragit med att analysera det sociala medborgarskapet i relation till LSS-lagstiftningen. I denna artikel har vi granskat äldreomsorgens omvandling utifrån tämligen likartade analytiska utgångspunkter. Artikelns uppgift har varit att både ge en genomlysning av äldreomsorgen utifrån begreppsparen socialt medborgarskap och sociala rättigheter men också som Gynnerstedt bidra med att konkretisera Marshalls ursprungliga begrepp för en analys av den sociala servicen.

Omvandlingen av äldreomsorgen under 1990-talets senare del kan ses som en process där biståndsprövningen i ökande grad formaliserats och äldreomsorgstjänsterna standardiserats. Denna ändring av praxis har medfört preciseringar av den enskildes rättigheter inom ramlagstiftningen. Den nya professionella gruppen biståndsbedömare har med sin administrativa/byråkratiska kompetensprofil blivit en länk som bidragit till detta. Man kan säga att de sociala rätttigheterna stärkts inom äldreomsorgen - de har blivit synligare och mer precisa och kanske mindre godtyckliga. Emellertid har detta skett parallellt med att de äldres egna problemformuleringar (tolkningsföreträde - både vad gäller omfattning och inriktning) i ökad grad fått stå tillbaka organisationsbestämda kriterier för kategorisering och sortering av hjälptagare uttryckta i biståndsbedömarnas granskning av behov och beslut om bistånd. Också en ökande klyfta mellan vad man som medborgare förväntar sig och vad man faktiskt får tycks ha uppstått. Det är pågående förändringar i organiseringen som avgör i vilken riktning det sociala medborgarskapet transformeras. Slutsatsen av vår argumentation ger vid handen att parallellt med att de sociala rättigheterna (rätten till bistånd) på ett formellt plan preciserats och i denna mening stärkts har det sociala medborgarskapet urholkats inom den svenska äldreomsorgen. Vårt exempel visar på att man inte a priori kan utgå från att mer preciserade formella rättigheter bidrar till att öka det sociala medborgarskapets innehåll.

Inom äldreomsorgen införs idag i många kommuner s k omsorgsgarantier. De innehåller både administrativa element exempelvis tidsgränser för när en handläggning måste ha skett och konkreta löften om insatser eller $\mathrm{m}$ a o utsagor om det materiella innehållet exempelvis att individen har rätt till att vistas utomhus en gång i veckan (Omsorgsgarantier inom äldre- och handikappomsorgen. Gävle kommun 2001). Det kan mycket väl visa sig att garantin blir en del i en fortsatt formalisering av bedömningskriterier och standardisering av insatser. Trots det flotta ordvalet kan garantin generellt sett leda till en försämring för de äldre om de »åtminstone»-formuleringar de innehåller blir standardnormer snarare än minimigarantier 


\section{Referenser}

Brubaker, W. Rogers (red) (1989) Immigration and Politics of Citizenship in Europe and North America. Lanham, New York, London: University Press of America

Brubaker, W. Rogers (1992) Citizenship and Nationhood in France and Germany. Cambridge, Mass: Harvard University Press

Blomberg, Staffan, Edebalk, Per Gunnar, Petersson, Jan (1999) Äldreomsorg utan service - en framgångsrik strategi. Meddelanden från Socialhögskolan: 1999:1

Daatland, S O, (red) (1997) De siste årene. Eldreomsorgen i Skandinavia 1960-95. NOVA-rapport Oslo

Eardley, T., J.Bradshaw, J. Ditch, I.Gough \& P. Whiteford (1996) Social Assistence in OECD countries. Volume 1: Synthesis Report. DSSR (Department of Social Security Research) Report Nr 46. London: HMSO

Edebalk, Per Gunnar(1990) Hemmaboendeideologins genombrott - åldringsvård och socialpolitik 19451965. Meddelanden från Socialhögskolan 1990:4

Edebalk, Per Gunnar(1991) Drömmen om ålderdomshemmet - aldringsvård och socialpolitik 19001952. Meddelanden från Socialhögskolan 1991:5

Esping-Andersen, Gösta (1990) Three Worlds of Welfare Capitalism. Cambridge: Polity Press

Giddens, Anthony (1998) The Third Way. London: Polity Press.

Gynnerstedt, Kerstin (2001) Medborgarskapsteorier i välfärdsfrågor - dimensioner och begrepp. Socialvetenskaplig tidskrift 2001:4

Hasenfeld, Yeheskel (1983) Human Service Organisations. New Jersey: Prentice Hall

Hetzler, Antoinette (1994) Socialpolitik i verkligheten. Lund: Bokbox

Hill, Michael (1997) The Policy Process in the Modern State. Harlow: Prentice Hall

Lindquist, Rafael, (red) (1998) Organisation och välfärdsstat. Lund: Studentlitteratur

Lipsky, Michael (1980) Street-Level Bureaucrazy. Dilemmas of the Individual in Public Services. New York: Russel Sage Foundation

Lorentz, Walter (1998) Socialt arbete i ett föränder- ligt Europa. Göteborg: Daidalos

Lödemel, Ivar (1997) The Welfare Paradox. Income Maintenance and Personal Social services in Norway and Britain 1946-1966. Oslo: Scandinavian University Press

Marshall, Tom.H (1950) Citizenship and Social Class. Cambridge: Cambridge University Press

Mishra, Ramesh (1981) Society and Social Policy. London: Macmillan

Möller, Tommy (1998) Politikerförakt eller mogen misstro? : misstron mot politiker och politiska institutioner: en översikt. Stockholm: Svenska kommunförbundet/Kommentus(distributör)

Omsorgsgarantier inom äldre- och handikappomsorgen, Gävle kommun. Informationsblad, november 2001

Premfors, Rune (1998) Den komplexa staten. I Ahrne, Göran (red) Stater som organisationer. Stockholm: Nerenius \& Santérus förlag

Prottas, Jeffrey (1979) People-processing: the street-level bureaucrat in public service bureaucracies. Lexington: Lexington books

Qvarsell, Roger (1993) Skall jag taga vara på min broder? Umeå: Institutionen för idéhistoria, Umeå universitet

Qvarsell, Roger (1995) Mellan familj, arbetsgivare och stat. I Amnå, Erik. (red.). Medmänsklighet att hyra. Örebro: Libris

Rothstein, Bo (1994) Vad bör staten göra? : om välfärdstatens politiska och moraliska logik. Stockholm: SNS

Socialstyrelsen (1996) Alternativa styr- och driftsformer $i$ äldreomsorgen. Äldreomsorg på entreprenad. SoS-rapport 1996:8. Stockholm: Socialstyrelsen

Socialstyrelsen (1999) Konkurrensutsättning och entreprenader inom äldreomsorgen. Äldreuppdraget 99:6

Stjernö, Steinar (1999) The Scandinavian Social Service Model. I Flösser, G och Otto, H-U (red) Towards More Democracy in Social Services

Sundström, Gerdt (1997) Rättvis äldreomsorg: är ransonering svaret? I Jennbert, K, Lagercrantz, R (red) Äldrepolitik i förändring?

Blomberg \& Petersson: Offentlig äldreomsorg som del i ett socialt medborgarskap 
Stockholm: Välfärdsprojektets skriftserie nr 9

Sunesson, Sune (1990) Att spränga fattigvårdsskalet. Ur Scenförändring. Meddelanden från Socialhögskolan, 1990:2.

Svensson, Marianne, Edebalk, Per Gunnar (2001) 90-talets anbudskonkurrens $i$ äldreomsorgen - några utvecklingstendenser. IHE Arbetsrapport 2001:1

Szebehely, Marta (1998a) Hjälp i hemmet i nedskärningstid - hemtjänstens och anhörigas insatser för gamla kvinnor och män. I Åt var och en efter behov. Rapport från programberedningen. Stockholm: Svenska Kommunförbundet

Szebehely, Marta (1998b) Omsorgsstat i förändring? I Välfärden - Verkan och Samverkan. Rapport från forskarseminariet i Umeå januari 1998. Stockholm: Försäkringskasseförbendet

Szebehely, Marta (1998c) Hustruns hjälp eller hemtjänstens? I Äldreomsorgens vardag. Konferensrapport. Stockholm: Socialvetenskapliga forskningsrådet

Szebehely, Marta (2000) Äldreomsorg i för- ändring - knappare resurser och nya organisationsformer. I SOU 2000:38 Välfärd, vård och omsorg. Stockholm: Fritzes

Titmuss, Richard (1974) Social Policy. London: Allen \& Unwin

Titmuss, Richard (1968) Committment to Welfare. London: Allen and Unwin

Tilly, Charles (1998) Durable Inequality. Berkley: University of California Press

Trydegård, Gun-Britt (2000) Tradition, change and variation: past and present trends in public old-age care. Stockholm: Institutionen för socialt arbete, Stockholm

Trydegård, Gun-Britt (2001) Välfärdstjänster till salu. I SOU 2001:52 Välfärdstjänster $i$ omvandling. Stockholm: Fritzes

Turner, Bryan S (ed) (1993) Citizenship and Social Theory. London: Sage

Åman, Anders (1976) Om den offentliga vården. Byggnader och verksamheter vid svenska vardinstitutioner under 1800- och 1900-talen. En arkitekturhistorisk undersökning. Uddevalla: Liber förlag och Sveriges Arkitekturmuseeum

\section{Summary}

\section{Public care of the elderly as a part of social citizenship}

Drawing on T. H. Marshall, the notion of social citizenship is applied in this article to the development of public care for the elderly in Sweden. Initially a historical résumé clarifies the change of elder care in Sweden as a move from a residual arrangement with its roots in the poor laws of the nineteenth century to become, during the 1960s and 1970s, an institutionalized public service commonly used by elderly citizens. It is shown, however, that during the 1990s features from the old model were recaptured through changes in the organization and practices of care delivery. The authors construct a model for making the term citizenship operational by the use of three dimensions regarding access, assessment and legitimacy. Leaning on empirical data (mostly interviews) from ongoing research in eight Swedish municipalities, it is shown that parallel to a formal strengthening of rights in elder care, the status of citizenship is weakened. This somewhat paradoxical conclusion is built around the necessity of distinguishing the formal status of social rights from the qualitative aspects of social citizenship. 